\title{
Comparative Analysis of Ergonomic Risk With QEC and REBA Method on The Souvenir Aceh Treater in UD. Ikhsan Aceh
}

\author{
Amri Sulaiman $^{1}$ and Cut Ita Erliana ${ }^{1}$ \\ \{iramri@unimal.ac.id\} \\ ${ }^{1}$ Department of Industrial Engineering, Universitas Malikussaleh, Aceh Utara, Indonesia
}

\begin{abstract}
UD. Ikhsan is one of Acehnese special embroidery souvenirs. The production process is tailoring done with long term work posture statistically this activity caused complaints from the workers. This study aims to identify the level of ergonomic risk by comparison of Quick Exposure Check and Rapid Entire Body Assessment methods. Data collection was done by distributing Nordic Body Map questionnaire and QEC questionnaire and taking posture when conducting sewing activity based on capture video camera. The results of NBM questionnaires show that workers are experiencing multiple complaints of musculoskeletal disorders. The body part of the complaint is $93 \%$ waistline, $87 \%$ buttocks, $87 \%$ lower neck, $80 \%$ left shoulder, $80 \%$ back and $80 \%$ right wrist. For QEC score calculations ranging from $50 \%-70 \%$, included in the next action category which means it needs further research and changes. The results of the calculation of the REBA method on the assessment of tailor work posture are obtained by operator operator $=5$ with high risk and level 2 with a medium category which means that action is needed. The cause of work risk based on the research is the factor of the operator's posture, work equipment and method.
\end{abstract}

Keywords: Ergonomics, Nordic Body Map, REBA, QEC

\section{Introduction}

Culture is a custom and characteristic of an area [1]. The Indonesian state is made up of various cultures, such diverse Indonesian cultures as beliefs, languages, dances, objects etc. Cultural heritage continues to be preserved and increasingly want to be developed and introduced to the world wide [2]. Aceh Province is one of the western regions of Indonesia which has a very unique culture both from language, social life, dance, food, objects such as; houses, clothing, carvings, and so on, as well as natural expanses that encourage and invite tourists to visit the region of Aceh. These perspectives also have an impact on the people of Aceh which are able to stimulate the economy and insight.

The development of tourism objects can create ideas to create products that can be sold to tourists without removing the culture of Aceh [3]. The products are produced in various forms that can be made souvenirs typical of Aceh, one of which is in the form of bags with embroidery typical of Aceh. Increased activity to run a souvenir business Aceh is very promising and provide great benefits. However, there are things that need to be considered in the production of souvenirs of Aceh conducted by tailors that is on postr work and work poster relationship on 
the workplace that can cause negative impacts that is, against muscle disorders and health complaints and at risk of work accidents.

Ergonomics can also be interpreted as a science that regulates posture, work, proper planning and prevention of occupational diseases such as low back pain and disorders of Musculoskeletal Disorders (MSDs) because basically work affects health in various ways [4].As for some tools that can be used in ergonomic risk to improve work system, Nordic Body Map questionnaire is a questionnaire that is used to know the discomfort at worker at work and method used for this research among others.

QEC (The Quick Exposure Check) is an assessment of occupational occupational risk (Musculoskeletal Disorders-MSDs), and REBA (Rapid Entire Body Assesment) is a regulation of body posture at work and an assessment of factors that affects Musculoskeletar Dissorders complaints. UD. Ikhsan located in Bungkah, is one of the artand producer of souvenir embroidery typical of Aceh with the product that is produced in the form of bags and wallets of various sizes . During this process of production of souvenirs of Aceh by using machines that are operated automatically and manually if there is power outages.

Generally use a new type of sewing machine and a rather large size with the help of engine dynamo to facilitate them in sewing and accelerate the completion of their stitching tasks. Bad work station condition will reduce the performance of the tailor and also can cause work risk within a certain period of time. In general, tailors who work with static movements for an excessive period of time in their work activities will be at risk for injuries such as muscle disorders or Musculoskeletal Disorders (MSDs) associated with ergonomic problems.

The results of preliminary observation note that in the process of Aceh souvenir design conducted by workers ranging from operating machines using legs to embroidery and sewing. From various phenomenon experienced by tailor by doing work condition of work posture in not ergonomic position with repetitive and static movement, long working hours from Monday to Saturday even week starting at 08.00 until 17.00 and continued by curfew at 09.00 until 22.00 and time break the less regular workers so that workers work longer. Complaints are usually painful on the back, at the waist, on the arms and buttocks due to static muscle loading.

\section{Literature Review}

The term ergonomics began in 1949, when it was formed by the Ergonomic Research Society in England. This resulted in the first journal in the field of ergonomics in November 1957. The International Ergonomics Association was formed in 1957 and The Human Factors Society in America in the same year [1].

Ergonomics is derived from the Greek ergon meaning work and 'nomos' which means law or rule so that ergonomics is a rule or law in doing work activity [2]. Simply stated, ergonomics is defined as the study of the interaction between humans and the objects it uses and with the environment in which such interactions occur [3].

According to Humantech [4] Musculoskeletal Disorders (MSDs) is a disorder caused by accumulation of injury or minor damage to the musculoskeletal system due to recurrent trauma that each time does not recover completely, thus forming considerable damage to cause pain. According to OSHA [5], MSDs are a set of symptoms associated with muscle tissue, tendons, ligaments, cartilages, nervous system, bone structure, and blood vessels. MSDs initially cause pain, pain, numbness, tingling, swelling, stiffness, shaking, sleep disturbances, and burning sensations.

According to the National Safety Council [6], MSDs can also be interpreted as a disorder of normal functioning of muscles, tendons, nerves, blood vessels, bones and ligaments due to changes in structure and changes in the musculoskeletal system. 
MSDs are injuries or diseases of the nervous system or tissues such as muscles, tendons, ligaments, joints, cartilage or blood vessels. The pain of MSDs can be described as rigid, inflexible, hot / burning, tingling, numbness, cold and discomfort. Musculoskeletal complaints are complaints on the skeletal muscle that is felt by someone ranging from mild complaints to painful complaints [7].

According to Humantech [8], symptoms of MSDs are often accompanied by complaints that are subjective, making it difficult to determine the severity of the disease. MSDs are characterized by symptoms such as pain, pain, discomfort, numbness, weakness or loss of power and hand coordination, burning sensation, mild movements, stiffness and cracks in joints, redness, swelling, heat, and pain keeping awake in the middle of the night and feeling to massage hands, wrists, and arms.

Musculoskeletal is the science of the muscular system and the skeleton or bone that is covered by the muscle. The term musculoskeletal consists of two words namely muscular and skeleton. Muscular means muscle and skeleton means bone or skeleton. Simply it can be concluded that musculoskeletal is a combination of muscle system and framework that adhesive with connective tissue that serves to facilitate the occurrence of movement in humans.

\section{Methods}

UD. Ikhsan is an Acehnese embroidery souvenir industry established by an individual by a civil servant (PNS) in 1980. History of UD. Ikhsan became the beginning of developing and the establishment of buildings to produce typical embroidery souvenirs of Aceh in Bungkah. Where the people of North Aceh, especially in Bungkah realize that this field of business has a bright prospect. In 2000 the father retired as a civil servant, resulting in UD ownership. Ikhsan was given to his son, Mr. Ikhsan. The production of bordir Aceh souvenirs has been marketed throughout Aceh and several cities in Indonesia to get to foreign countries like America. Sales each month increase with an average sales of 150-500 units.

The work that became the object of the writer's observation was the tailor of Aceh embroidered souvenirs who worked in informal venues that belonged to similar industrial areas. Generally workers come and live close to UD. Ikhsan in Bungkah area. When working workers using a vehicle or on foot only takes a maximum of 15 minutes to get to work. Work activities undertaken are analyzed as follows:

1. Sewin.

In doing the job of sewing clothes, each worker usually works in accordance with the capabilities and production targets that have been determined by the business actor. Long working hours from Monday to Saturday and even Sunday from 08.00 to 17.00, and continued by curfew at 20:00 to 23:00. There is no standard provision for length of working time and many minimal clothing to be completed by workers. There are only rest periods that are almost valid for all employees such as lunch breaks and prayers at 12:00 to 13:00 and afternoon breaks from 5:00 pm to 8:00 pm. Outside of these breaks, each worker is given the freedom to continue or complete production targets if not resolved at night. This happens because most of the workers or employees who work as a tailor is domiciled around or even in the home business that has been provided. From the observation, the aspects that can be considered to get a picture of activities and work locations, namely:

a. Seats

From the results of observations in the field, all the tailors use the same seat form of wooden or plastic chairs that do not have a backrest. Seats are only given pads to avoid the pads on the buttocks. Seats are commonly used by tailors as in Figure 4.1 below. 


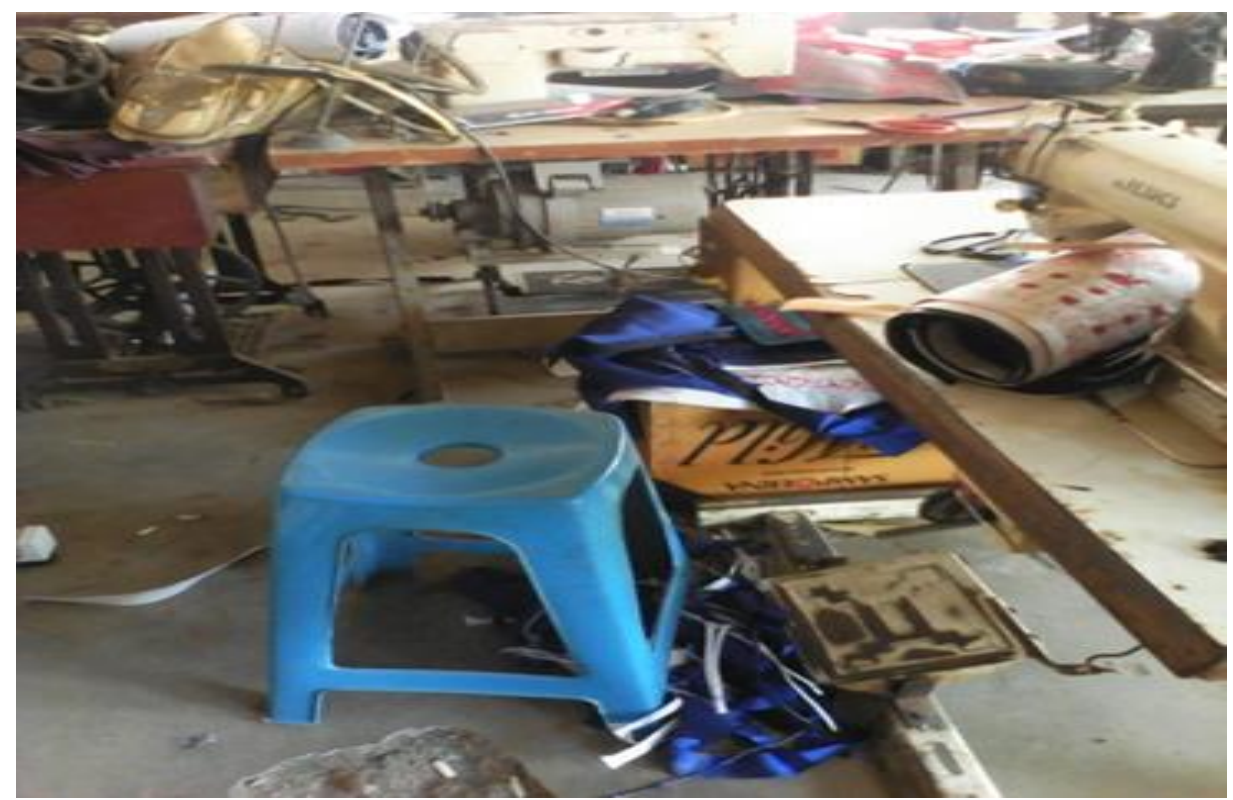

Figure 1 . Seats commonly used by tailors

b. Sewing Machine

For the type of sewing machine that is generally used by workers, there is no difference in the machine used by this tailor. They generally use a new type of sewing machine and a rather large size with the help of engine dynamo to facilitate them in sewing and accelerate the completion of their stitching tasks.

\section{Results and Discussion}

In general, workers who work in this sector of informal sewing sector background of lower education with education levels ranging from not graduating elementary school until high school.Tidak workers who finish education or continue education to college level. However, there are 2 seamsters are still a student status that is sitting in high school. For their knowledge of sickness complaints many of them are still confused to explain because they reasoned that at the time of filling the questionnaire they are not in a state of pain or muscle pain as described in the questionnaire Nordic body map and Quicks Expossure Check.

Table 1. Characteristic of Male and Female Tailors 


\begin{tabular}{|c|c|c|c|c|c|c|c|}
\hline $\begin{array}{c}\text { Operator } \\
\text { Name }\end{array}$ & $\begin{array}{c}\text { Age } \\
\text { (Year) }\end{array}$ & $\begin{array}{c}\text { Sex } \\
(\mathbf{M} / \mathbf{F})\end{array}$ & $\begin{array}{c}\text { Working } \\
\text { Time }\end{array}$ & $\begin{array}{c}\text { Length } \\
\text { of Work }\end{array}$ & $\begin{array}{c}\text { Height } \\
\text { (cm) }\end{array}$ & $\begin{array}{c}\text { Weight } \\
\text { (kg) }\end{array}$ & Smoking \\
\hline 1. Masnur & 28 & $\mathbf{M}$ & 2,4 Year & 10 & 166 & 56 & Yes \\
\hline 2. Ikhsan & 24 & $\mathbf{M}$ & 9 Year & 10 & 175 & 60 & No \\
\hline 3. Risky & 23 & $\mathbf{M}$ & 1,2 Year & 10 & 160 & 60 & Yes \\
\hline 4. Muhammad & 35 & $\mathbf{M}$ & 8 Month & 10 & 169 & 67 & Yes \\
\hline 5. Risky M. & 45 & $\mathbf{M}$ & 2 Year & 10 & 160 & 65 & Yes \\
\hline 6. Rahmadi & 18 & $\mathbf{M}$ & 1 Year & 5 & 155 & 58 & Yes \\
\hline 7. Wahyu & 28 & $\mathbf{M}$ & 2,4 Year & 10 & 168 & 63 & Yes \\
\hline 8. Zakir & 33 & $\mathrm{M}$ & 1,8 Year & 10 & 165 & 64 & No \\
\hline 9. Rahmat & 22 & $\mathbf{M}$ & 3 Year & 10 & 160 & 50 & Yes \\
\hline 10. Sukri & 20 & $\mathbf{M}$ & 8 Month & 10 & 158 & 54 & Yes \\
\hline 11. Rahmady & 23 & $\mathbf{M}$ & 8 Month & 10 & 158 & 62 & Yes \\
\hline 12. Fakhr1 R. & 25 & $\mathbf{M}$ & 7 Year & 10 & 170 & 65 & Yes \\
\hline 13. Abdul H. & 40 & $\mathbf{M}$ & 5 Year & 10 & 165 & 55 & Yes \\
\hline 14. Ibnu Jaril & 28 & $\mathbf{M}$ & 1 Year & 10 & 160 & 68 & Yes \\
\hline 15. Putri Jesa & 16 & $F$ & 2 Year & 5 & 140 & 35 & No \\
\hline
\end{tabular}

Source: Result Observation at UD.Ikhsan

Complaints of musculoskeletal disorders in all workers can be seen in table 2 .

Table 2. Complaints Musculoskeletal Disorder In All Workers Tailor.

\begin{tabular}{|c|c|c|c|c|c|}
\hline \multirow{3}{*}{ No } & \multirow{3}{*}{ Part of Body } & \multicolumn{4}{|c|}{ Musculoskeletal disorder complaints } \\
\hline & & \multicolumn{2}{|c|}{ Sick } & \multicolumn{2}{|c|}{ No Sick } \\
\hline & & Amount & $\%$ & Amount & $\%$ \\
\hline 0 & Upper neck & 11 & $73 \%$ & 4 & $27 \%$ \\
\hline 1 & Lowver neck & 13 & $87 \%$ & 2 & $13 \%$ \\
\hline 2 & Left shoulder & 12 & $80 \%$ & 3 & $20 \%$ \\
\hline 3 & Right ahoulder & 11 & $73 \%$ & 4 & $27 \%$ \\
\hline 4 & Left upper arm & 6 & $40 \%$ & 9 & $60 \%$ \\
\hline 5 & Back & 12 & $80 \%$ & 3 & $20 \%$ \\
\hline 6 & Upper right arm & 6 & $40 \%$ & 9 & $60 \%$ \\
\hline 7 & Waigt & 14 & $93 \%$ & 1 & $7 \%$ \\
\hline 8 & Buttocks & 10 & $67 \%$ & 5 & $33 \%$ \\
\hline 9 & Butt & 13 & $87 \%$ & 2 & $13 \%$ \\
\hline 10 & Left elbow & 5 & $33 \%$ & 10 & $67 \%$ \\
\hline 11 & Right elbow & 5 & $33 \%$ & 10 & $67 \%$ \\
\hline 12 & The left arm is left & 1 & $7 \%$ & 14 & $93 \%$ \\
\hline 13 & Right arm down & 3 & $20 \%$ & 12 & $80 \%$ \\
\hline 14 & Left wrist & 4 & $27 \%$ & 11 & $73 \%$ \\
\hline 15 & Right wrigt & 12 & $80 \%$ & 3 & $20 \%$ \\
\hline 16 & Left hand & 6 & $40 \%$ & 9 & $60 \%$ \\
\hline 17 & Right hand & 5 & $33 \%$ & 10 & $67 \%$ \\
\hline 18 & Left thigh & 6 & $40 \%$ & 9 & $60 \%$ \\
\hline 19 & Right thigh & 7 & $47 \%$ & 8 & $53 \%$ \\
\hline 20 & Left knee & 2 & $13 \%$ & 13 & $87 \%$ \\
\hline 21 & Right knee & 1 & $7 \%$ & 14 & $93 \%$ \\
\hline 22 & Left calf & 7 & $47 \%$ & 8 & $53 \%$ \\
\hline 23 & Right calf & 10 & $67 \%$ & 5 & $33 \%$ \\
\hline 24 & Left ankle & 3 & $20 \%$ & 13 & $87 \%$ \\
\hline 25 & Right ankle & 5 & $33 \%$ & 11 & $73 \%$ \\
\hline 26 & Left foot & 3 & $20 \%$ & 12 & $80 \%$ \\
\hline 27 & Right foot & 7 & $47 \%$ & 8 & $53 \%$ \\
\hline
\end{tabular}


From the results of observation and assessment in the table above found that most complaints on workers are on the upper neck, waist, and right wrist. This is caused by an awkward posture when doing the work of making patterns and cut the pattern and also because the layout and the height of the table commonly used to perform his work is still not in accordance with the physical form and posture of the worker.

Based on the results of the distribution of questionnaires and recapitulation Nordic Body Map (NBM) to all respondents conducted to 15 workers. The intended complaint is the symptoms of pain felt by the worker after or while performing his work on a particular body part. The pain can be only one part of the body or a combination of aches, pains, tingling, heat, seizures, cramps, swelling, stiffness and numbness.

From the results of the assessment, respondents who stated musculoskeletal disorders complaints in certain sections are classified into 4 categories with the following classification:

a. $0-24 \%$ of respondents claimed to have a complaint on the part described by white color

b. $25-49 \%$ of respondents claimed to have a complaint on the part described by white color

c. $50-74 \%$ of respondents claimed to have a complaint on the part described with orange color

d. $75-100 \%$ of respondents claimed to have a complaint on the part described with the color.

The Nordic body map illustrates the parts of the body that are complained of illness and body parts that have few complaints of pain as in Figure 2 below.

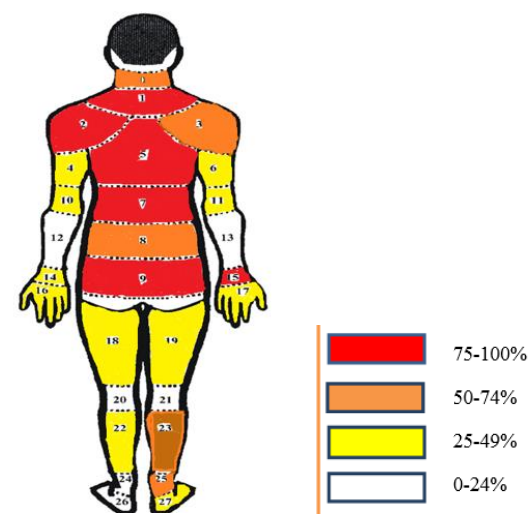

Figure 2. Pictures of pain complaints on the tailor's body

From the picture Nordic body map (NBM) above note that the red body part of the body is part of the body who complained most of the same more than $75 \%$. On the NBM cross section, it is known that the body parts that most experienced pain complaints are in the lower part of the neck, left shoulder, back, waist, and right wrist.

From the characteristics of work done by the workers on this tailor, it can be seen that the work of sewing is mostly done in a state of posture that is static or fixed that is in the sitting and body that often experience the movement is on the right hand, left hand and right foot . 
The position of the body sitting on a plastic or wooden chair without a backrest causes most of these tailors always bent over to lead sewing machines. The right wrist performs the activity of rotating the material, cutting the material when it is excessive.

The right foot always performs repetitive movements such as stepping on the dynamo of the sewing machine which emits vibration from the engine direction to the worker's leg part from the right ankle, calf, knee, thigh up to the body, so that the right calf and right ankle have complaints on tailor experienced as many as $67 \%$ and $33 \%$.

Where in parts of the body given orange color indicates that about $50-74 \%$ of workers have complaints on the upper part, buttocks and right shoulder. The yellow part of the body indicates that the worker has a $25-49 \%$ complaints on the upper left arm, right upper arm, left elbow, right elbow, right wrist, left hand, right hand, left thigh, right thigh, left calf and right foot. These complaints can be caused by the work posture and layout of the table used are still not in accordance with the physical condition and the body posture work as well as poor lighting conditions coupled with striped or dark colored material motifs also impose their body and eyes to be able to see the path of the seams on the pattern which will be sewn.

So that the conditions of this kind of work that causes the workers when sewing and install a supplement bagbekerja with awkward posture.In accordance with the characteristics of work and work location experienced by tailors in UD. This Ikhsan causes complaints on the above body parts sufficiently experienced by many workers. White color on the body shows that about $0-24 \%$ of the body is very rarely complained is on the left forearm, right forearm, left and right knee and left wrist. This is indeed on the body has a pedestal or backrest is quite comfortable This can be due to work posture and layout of the table used is still not in accordance with the physical condition and worker posture so that it can minimize the risk of complaints and muscle pain or skeletal known as musculoskeletal disorders (MSDs).

\section{Conclusions}

Based on the results of research conducted by researchers, it can be concluded as follows:

1. Based on Nordic Body Map calculations of 15 tailors subjected to subjective complaints of Musculoseletal Disorders (MSDs) and showed mixed results. Body parts that have complaints $93 \%$ waist, $87 \%$ ass, $87 \%$ lower neck, $80 \%$ left shoulder, $80 \%$ back, right wrist $80 \%$.

2. Based on the calculation using QEC Exposure score level method has a value of $50 \%-70 \%$ it shows a high enough value which means the next action needs further research and changes are made.

3. Based on the result of calculation using REBA method to assessment of work posture on tailor known from result of calculation of REBA worksheet value of operator score is 6 with medium level and action level 2 which means action needed. The results of calculations with QEC and REBA methods show high results. Where QEC calculation results are measured based on muscle disturbance experienced by workers in the workplace while REBA is measured based on worker posture while doing the work.Calculations by QEC method were measured based on muscle disturbance experienced by workers at work with high ergonomic risk values whereas and REBA was measured based on worker posture when sewing with ergonomic risk values were moderate. This shows a higher QEC score and both indicate the need for improved facilities and posture position of the worker in order to be more effective, comfortable and no injury while doing the work. 


\section{References}

[1] Adha, Ezi Rezia. Usulan Perbaikan Stasiun Kerja pada PT. Sinar Advertama Servicindo (SAS) Berdasarkan Hasil Evaluasi Menggunakan Metode Quick Exposure Check (QEC). Jurnal Online Institut Tennologi Nasional. 2016.

[2] Budhiman, Meitama Arief. Analisis Penilaian Tingkat Resiko Ergonomi Pada Pekerja Kontruksi Proyek Ruko Graha Depok Tahun 2015. 2016.

[3] Bernard, B. P 1997. Musculoskeletal Disorders and Workplace Factors: A Critical Review of Epidemiologi Evidence for Work-related Muculoskeletal Disorders of The Neck, Upper Extrimity and Low Back. Cincinnati: NIOSH.

[4] Bridger, R. S. 1995. Introduction to Ergonomics. Singapore: McGraw-Hill, Inc.

[5] Grandjen, E. 1993. Fitting The Task to The Man, A Tex Book Of Occupational Ergonomic, \$ th edition, London : Taylor and Francis Ltd

[6] Halibona, Djaka. Identifikasi Risiko Ergonomi Dengan Metode QEC, Nordic Body Map Dan REBA. 2016.

[7] Ilham, dkk. 2013. Rancangan Perbaikan Sistem Kerja Dengan Metode Quick Exposure Check (QEC) Di Bengkel Sepatu X Di Cibubut. Jurnal Online Institut Tennologi Nasional. 2016.

[8] Martaleo, Meity. 2012. Perbandingan Penilaian Risiko Ergonomi Dengan Metode REBA Dan QEC (Studi Kasus Pada Kuli Angkut Terigu). Simposium Nasional RAPI XI FT UMS.

[9] Nurmianto, Eko. 2004. Ergonomi Konsep Dasar dan Aplikasinya. Surabaya: Guna Widya.

[10] NIOSH. 2007. Ergonomics Guidelines For Manual Handling. DHHS (NIOSH). Publication No 2007-131. Columbia. NIOSH/CDC.

[11] Oborne, David J. 1995. Ergonomics at Work: Third Edition. England: John Wiley and Sons Ltd.

[12] Pheasant, Stephen. 1999. Bodyspaces. Great Britain: TJ International Ltd. Padstow Cornwall.

[13] Pulat, B. Mustafa. 1992. Fundamentals of Industrial Ergonomics. New Jersey: PrenticeHall, Inc.

[14] Suma'mur, P.K. 1989. Ergonomi untuk Produktivitas Kerja. Jakarta: CV Haji Mas Agung.

[15] Tarwaka, dkk. 2004. Ergonomi Untuk Keselamatan, Kesehatan Kerja, dan Produktivitas. Surakarta: Uniba Pers. 